\title{
3-Hydroxy-3-Methylglutaryl-Coenzyme A Reductase
}

\author{
A COMPARISON OF THE MODULATION IN VITRO BY PHOSPHORYLATION AND \\ DEPHOSPHORYLATION TO MODULATION OF ENZYME ACTIVITY BY FEEDING \\ CHOLESTEROL- OR CHOLESTYRAMINE-SUPPLEMENTED DIETS
}

\author{
Konstantinos A. MITROPOULOS, Brian L. KNIGHT and Bernard E. A. REEVES \\ Medical Research Council Lipid Metabolism Unit, Hammersmith Hospital, London W12 0HS, U.K.
}

(Received 25 July 1979)

\begin{abstract}
The activity of 3-hydroxy-3-methylglutaryl-coenzyme A reductase (hydroxymethylglutaryl-CoA reductase) was considerably inhibited during incubation with ATP $+\mathrm{Mg}^{2+}$. The inactivated enzyme was reactivated on further incubation with partially purified cytosolic phosphoprotein phosphatase. The inactivation was associated with a decrease in the apparent $K_{\mathrm{m}}$ of the reductase for hydroxymethylglutaryl-CoA, and this was reversed on reactivation. The slight increase in activity observed during incubation of microsomal fraction without ATP was not associated with a change in apparent $K_{\mathrm{m}}$ and, unlike the effect of the phosphatase, was not inhibited by NaF. Liver microsomal fraction from rats given cholesterol exhibited a low activity of hydroxymethylglutaryl-CoA reductase with a low apparent $K_{\mathrm{m}}$ for hydroxymethylglutaryl-CoA. Mícrosomal fraction from rats fed cholestyramine exhibited a high activity with a high $K_{\mathrm{m}}$. To discover whether these changes had resulted from phosphorylation and dephosphorylation of the reductase, microsomal fraction from rats fed the supplemented diets and the standard diet were inactivated with ATP and reactivated with phosphoprotein phosphatase. Inactivation reduced the maximal activity of the reductase in each microsomal preparation and also reduced the apparent $K_{\mathrm{m}}$ for hydroxymethylglutaryl-CoA. There was no difference between the preparations in the degree of inactivation produced by ATP. Treatment with phosphatase restored both the maximal activity and the apparent $K_{\mathrm{m}}$ of each preparation, but never significantly increased the activity above that observed with untreated microsomal fraction. It is concluded that hydroxymethylglutaryl-CoA reductase in microsomal fraction prepared by standard procedures is almost entirely in the dephosphorylated form, and that the difference in kinetic properties in untreated microsomal fraction from rats fed the three diets cannot be explained by differences in the degree of phosphorylation of the enzyme.
\end{abstract}

The liver plays an important role in the homoeostasis of sterol in the body. It supplies the majority of the endogenously synthesized cholesterol, and can alter the rate of synthesis to accommodate the changing requirements for cholesterol in the whole animal. Thus, variations in the intake of cholesterol from the diet, or in the rate of return of bile acids from the enterohepatic circulation, are associated with compensatory changes in the rate of cholesterol synthesis in the liver. The rate-limiting step for the biosynthesis of cholesterol is considered to be the reduction of 3-hydroxy-3-methylglutaryl-coenzyme A to mevalonic acid (Rodwell et al., 1973; Dietschy \& Brown, 1974) catalysed by the enzyme 3hydroxy-3-methylglutaryl-coenzyme A reductase (hydroxymethylglutaryl-CoA reductase; EC 1.1.1.34). It has been shown with many tissues that changes in the activity of the enzyme closely follow changes in the overall rate of cholesterol synthesis over a wide variety of experimental conditions. The molecular mechanism by which the activity of hydroxymethylglutaryl-CoA reductase is altered in vivo is not clear. It has been accepted for a number of years that the activity of the enzyme can be controlled at the level of protein synthesis or degradation (Rodwell et al., 1973). However, a number of recent observations cannot be adequately explained by such a mechanism and have suggested that the activity of hydroxymethylglutaryl-CoA reductase can also be modulated directly (Higgins \& Rudney, 1973; Brown \& Goldstein, 1974).

We have proposed that hydroxymethylglutarylCoA reductase can be influenced by the size of a pool of cholesterol in the endoplasmic-reticular 
membrane in the immediate environment of the enzyme (Mitropoulos \& Venkatesan, 1977). In rat liver, the decrease in the activity of hydroxymethylglutaryl-CoA reductase that follows the administration of dietary cholesterol (Mitropoulos \& Venkatesan, 1977), intravenous mevalonic acid (Mitropoulos et al., 1978b) or unsaturated dietary fat (K. A. Mitropoulos, unpublished work) is associated with an increase in the size of this pool of cholesterol. The increase in the activity of the enzyme after the partial interruption of the enterohepatic circulation (Mitropoulos \& Venkatesan, 1977), biliary obstruction (Mitropoulos et al., 1979) or Triton WR1335 administration (Mitropoulos et al., 1978a) is associated with a decrease in the size of the pool.

In 1973, it was reported that the activity of hydroxymethylglutaryl-CoA reductase was reduced after incubation of the microsomal fraction with $\mathrm{ATP}+\mathrm{Mg}^{2+}$ (Beg et al., 1973), and that this effect could be reversed by incubating the inactivated enzyme with a protein fraction from the cytosol. This reversible inactivation of hydroxymethylglutaryl-CoA reductase was confirmed in several laboratories (Brown et al., 1975; Chow et al., 1975; Berndt et al., 1976; Nordstrom et al., 1977; George et al., 1978; Goodwin \& Margolis, 1978) and has been attributed to covalent modification of the enzyme by a cycle of phosphorylation and dephosphorylation (Beg et al., 1978). The demonstration in vitro that hydroxymethylglutaryl-CoA reductase can exist in an active and inactive form provides a possible mechanism for the rapid short-term regulation of the enzyme, although evidence that such a mechanism operates in vivo is lacking.

To discover whether the inactivation and reactivation of hydroxymethylglutaryl-CoA reductase that is associated with phosphorylation and dephosphorylation plays a part in the modulation of the enzyme by cholesterol in vivo, we have compared its activity and isothermic kinetics before and after modulation in vitro in microsomal preparations from rats given cholestyramine, cholesterol and the standard diet.

\section{Materials and Methods}

The sources of radiolabelled compounds and other materials used in the present work have been reported elsewhere (Mitropoulos et al., 1978b).

\section{Housing and feeding of rats}

Male Wistar rats weighing $180-220 \mathrm{~g}$ were used for all experiments. The rats were kept under conditions of controlled lighting and feeding as described previously (Mitropoulos et al., 1973). The composition of the standard diet and the preparation of the diets supplemented with cholesterol $(2 \%)$ or with cholestyramine $(5 \%)$ has been reported elsewhere
(Mitropoulos et al., 1973). Cholestyramine-fed rats were given cholestyramine-containing pellets for 4 days before the experiment. Cholesterol-fed rats were presented with cholesterol-containing pellets for $12 \mathrm{~h}$ before the experiment. All rats were killed at 07:00 $\mathrm{h}$ on the day of the experiment and the livers were removed at once.

\section{Preparation of liver microsomal fraction and assay} of hydroxymethylglutaryl-CoA reductase

The livers were chilled on ice and perfused with ice-cold $0.25 \mathrm{M}$-sucrose to remove contaminating blood. The pooled livers from three rats in each group were then minced in a stainless-steel mincer and homogenized in 4 vol. of ice-cold $0.25 \mathrm{M}$-sucrose containing 1.5 mM-disodium EDTA, pH 7.4, with 25 strokes in a manually operated Potter-Elvehjem homogenizer. The microsomal pellet was obtained as described previously (Balasubramaniam et al., 1978). The microsomal fraction was prepared by suspending the microsomal pellet in $50 \mathrm{~mm}$-imidazole/ $\mathrm{HCl}$ buffer, $\mathrm{pH} 7.4$, containing $250 \mathrm{~mm}-\mathrm{NaCl}$ and $10 \mathrm{~mm}$-dithiothreitol, with eight strokes in a Potter-Elvehjem homogenizer. The microsomal fraction contained, in each $\mathrm{ml}$, the microsomes recovered from $0.5 \mathrm{~g}$ fresh weight of liver $(8-10 \mathrm{mg}$ of protein).

The activity of hydroxymethylglutaryl-CoA reductase was measured in a portion of the microsomal preparation with $0.6 \mathrm{ml}$ of assay mixture in a total volume of $1 \mathrm{ml}$. The assay mixture contained $0.1 \mathrm{M}$-potassium phosphate and $5 \mathrm{~mm}$-dithiothreitol buffer, $\mathrm{pH}$ 7.4, NADPH-generating system and DLhydroxymethyl[ $\left.3-{ }^{14} \mathrm{C}\right]$ glutaryl-CoA (sp. radioactivity $6 \mathrm{Ci} / \mathrm{mol}$ ) (Mitropoulos \& Venkatesan, 1977) at the concentration indicated. Microsomal preparations from rats on the three dietary conditions incubated with $180 \mu \mathrm{M}$-DL-hydroxymethylglutaryl-CoA under the conditions of the present experiments gave enzyme activity that was in all cases linear with respect to time and to protein concentration (in the range used).

\section{Phosphoprotein phosphatase}

Phosphoprotein phosphatase in the $104000 \mathrm{~g}$ supernatant fraction of rat liver was purified up to the ethanol-precipitation stage of the method described by Brandt et al. (1975). The ethanol-precipitated material was extracted twice with $50 \mathrm{~mm}$-imidazole buffer, $\mathrm{pH} 7.4$, containing $5 \mathrm{mM}$-EDTA and $0.5 \mathrm{~mm}$-dithiothreitol, and the combined extracts were dialysed against the same buffer containing $50 \%$ glycerol. Phosphoprotein phosphatase in this preparation, assayed as the release of inorganic phosphate, exhibited a specific activity of $2.5 \mathrm{nmol} / \mathrm{min}$ per $\mathrm{mg}$ of protein with $3 \mu \mathrm{M}$-phosphorylase as substrate and $2.1 \mathrm{nmol} / \mathrm{min}$ per $\mathrm{mg}$ of protein with $10 \mu \mathrm{M}$-phosphorylated histone as sub- 
strate. The activity was stable for at least 3 months if stored at $-20^{\circ} \mathrm{C}$ in the presence of $50 \%$ glycerol.

\section{Results}

Inactivation of hydroxymethylglutaryl-CoA reductase by $\mathrm{ATP}+\mathrm{Mg}^{2+}$ and reactivation by phosphatase

Preincubation of rat liver microsomal fractions in the presence of $2 \mathrm{mM}-\mathrm{ATP}$ and $4 \mathrm{mM}-\mathrm{MgCl}_{2}$ resulted in a time-dependent inhibition of hydroxymethylglutaryl-CoA reductase. Maximum inhibition under these conditions was obtained after 15-20 min (Fig. 1). The activity of the enzyme slightly recovered during further preincubation. Preincubation in the absence of ATP $+\mathrm{Mg}^{2+}$, or in its presence but with $25 \mathrm{~mm}$-EDTA, produced a $30 \%$ increase in activity that was not inhibited by $50 \mathrm{~mm}-\mathrm{NaF}$. The presence of $50 \mathrm{~mm}-\mathrm{NaF}$ during the assay of the enzyme

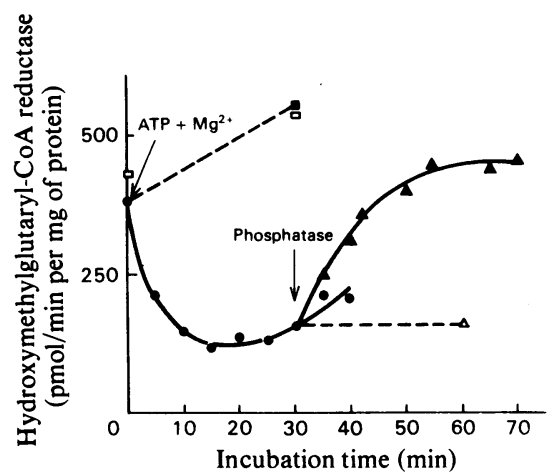

Fig. 1. Inactivation and reactivation of hydroxymethylglutaryl-CoA reductase in the rat liver microsomal fraction

Incubations contained, in a total volume of $0.2 \mathrm{ml}$, $50 \mathrm{~mm}$-imidazole $/ \mathrm{HCl} / 250 \mathrm{~mm}-\mathrm{NaCl} / 5 \mathrm{~mm}$-dithiothreitol (pH 7.4) buffer plus $2 \mathrm{~mm}$-ATP and $4 \mathrm{~mm}$ $\mathrm{MgCl}_{2}(\mathbf{O})$ and were incubated at $37^{\circ} \mathrm{C}$. Control incubations contained no ATP or $\mathrm{MgCl}_{2}$ ( $\square$ ) or no ATP and $\mathrm{MgCl}_{2}$ but $50 \mathrm{~mm}-\mathrm{NaF}(\square)$. All incubations contained $1.04 \mathrm{mg}$ of microsomal protein. At the indicated times, $0.2 \mathrm{ml}$ of $50 \mathrm{~mm}$-EDTA and $0.6 \mathrm{ml}$ of assay mixture were added and the sample was incubated for $30 \mathrm{~min}$ to assay the activity of hydroxymethylglutaryl-CoA reductase. For the reactivation reaction $0.2 \mathrm{ml}$ of $50 \mathrm{~mm}$-EDTA was added at the end of $30 \mathrm{~min}$ and the reaction was initiated by the addition of $2.75 \mathrm{mg}$ of phosphatase. At the indicated time intervals $50 \mathrm{~mm}-\mathrm{NaF}$ and the assay mixture were added and the activity of hydroxymethylglutaryl-CoA reductase was determined in a final assay volume of $1 \mathrm{ml}(\boldsymbol{\Delta})$. Control incubations contained either no phosphatase or contained phosphatase together with $50 \mathrm{mM}-\mathrm{NaF}$ $(\triangle)$. No difference between the two controls was observed. resulted in a $10 \%$ increase in activity, whereas the presence of $25 \mathrm{mM}$-EDTA had no effect. Fig. 1 also shows the time-dependence of the reactivation reaction catalysed by the partially purified cytosolic phosphatase. With $2.75 \mathrm{mg}$ of phosphatase preparation per $\mathrm{mg}$ of microsomal protein, a plateau activity was reached $30 \mathrm{~min}$ after the addition of phosphatase. In this experiment, the reactivated enzyme exhibited an activity that was about $20 \%$ less than that assayed after $30 \mathrm{~min}$ of preincubation with no additions, and $15 \%$ more than that assayed in the non-preincubated enzyme. The reactivation reaction was dependent on the concentration of phosphatase below $1 \mathrm{mg}$ of phosphatase protein (results not shown), and was blocked by the presence of $50 \mathrm{~mm}$ $\mathrm{NaF}$.

Preincubation of the microsomal fraction with $\mathrm{ADP}+\mathrm{Mg}^{2+}$ also produced an inactivation of hydroxymethylglutaryl-CoA reductase. However,

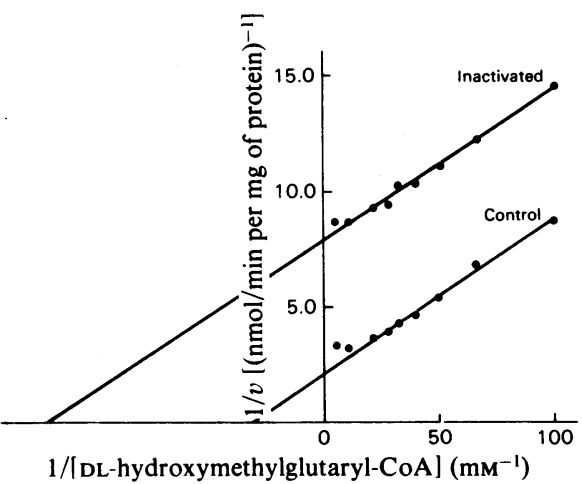

Fig. 2. Lineweaver-Burk plots of hydroxymethylglutaryl-CoA reductase in the microsomal preparation from rats given the standard diet with and without inactivation

Portions of the microsomal fraction $(8.25 \mathrm{mg}$ of protein) were incubated at $37^{\circ} \mathrm{C}$ for $20 \mathrm{~min}$ in a total volume of $2 \mathrm{ml}$ containing $50 \mathrm{~mm}$-imidazole $/ \mathrm{HCl} / 250 \mathrm{mM}-\mathrm{NaCl} / 5 \mathrm{mM}$-dithiothreitol $\quad(\mathrm{pH}$ 7.4) buffer plus $2 \mathrm{mM}-\mathrm{ATP}$ and $4 \mathrm{mM}-\mathrm{MgCl}_{2}$ for the inactivated, or no ATP or $\mathrm{MgCl}_{2}$ for the control. At the end of the incubation $2 \mathrm{ml}$ of $50 \mathrm{~mm}$ EDTA and $2 \mathrm{ml}$ of $150 \mathrm{~mm}-\mathrm{NaF}$ containing $25 \%$ glycerol were added to each preparation and $0.2 \mathrm{ml}$ portions were removed to assay the activity of hydroxymethylglutaryl-CoA reductase in a total volume of $0.5 \mathrm{ml}$ and in the presence of varied concentrations of DL-hydroxymethyl[ $\left.3-{ }^{14} \mathrm{C}\right]$ glutarylCoA $(10-180 \mu \mathrm{M}$; sp. radioactivity $6 \mathrm{Ci} / \mathrm{mol})$. The $V_{\max }$ and $K_{\mathrm{m}}$ values for DL-hydroxymethylglutaryl-CoA obtained in this experiment are $126.5 \mathrm{pmol} / \mathrm{min}$ per $\mathrm{mg}$ of protein and $8.3 \mu \mathrm{M}$ for the microsomal preparation preincubated in the presence of ATP $+\mathrm{Mg}^{2+}$ and $420 \mathrm{pmol} / \mathrm{min}$ per $\mathrm{mg}$ of protein and $33.3 \mu \mathrm{M}$ for the preparation preincubated in the absence of ATP $+\mathrm{Mg}^{2+}$. 
maximum inactivation was achieved much sooner than with ATP, and the activity rapidly recovered. In two separate experiments, hydroxymethylglutaryl-CoA reductase activity decreased to some $40 \%$ of control values after 5-10 min of incubation with $2 \mathrm{mM}-\mathrm{ADP}$ plus $4 \mathrm{mM}-\mathrm{MgCl}_{2}$, and recovered to reach approx. $75 \%$ of control values after $30 \mathrm{~min}$ incubation.

Influence of inactivation by $\mathrm{ATP}+\mathrm{Mg}^{2+}$ and reactivation by phosphatase on the isothermic kinetic properties of hydroxymethylglutaryl-CoA reductase

It has been shown previously (Mitropoulos \& Venkatesan, 1977) that cholesterol or cholestyramine feeding produces considerable changes, not only in the activity of hydroxymethylglutaryl-CoA reductase in liver microsomes, but also in the apparent $K_{\mathrm{m}}$ of the enzyme for hydroxymethylglutaryl-CoA. Apparent $K_{\mathrm{m}}$ values were low in the microsomal fraction from rats given cholesterol, and high in microsomes from rats fed cholestyramine. Since phosphorylation and dephosphorylation also produce a considerable modulation of the activity of hydroxymethylglutaryl-CoA reductase, we studied the isothermic kinetics of the enzyme in microsomes after inhibition with ATP $+\mathrm{Mg}^{2+}$ and reactivation with phosphatase. The microsomal fraction from rats fed the standard diet was incubated for $20 \mathrm{~min}$ at $37^{\circ} \mathrm{C}$ either with or without $2 \mathrm{mM}-\mathrm{ATP}+4 \mathrm{mM}$ $\mathrm{MgCl}_{2}$. Fig. 2 shows the double-reciprocal plots of reductase activity versus the concentration of substrate for the two preparations. Maximal activity $\left(V_{\max }\right)$ for the preparation preincubated in the presence of $\mathrm{ATP}+\mathrm{MgCl}_{2}$ was $26 \%$ of the corres- ponding value for the preparation preincubated without $\mathrm{ATP}+\mathrm{Mg}^{2+}$. Inactivation with ATP also reduced the apparent $K_{\mathrm{m}}$ for hydroxymethylglutaryl-CoA. Similar effects of inactivation on the $V_{\max .}$ and $K_{\mathrm{m}}$ values of hydroxymethylglutaryl-CoA reductase were observed in another experiment with a different group of rats (Table 1). In this experiment, the inactivation reaction was stopped after $20 \mathrm{~min}$ by the addition of $25 \mathrm{~mm}$-EDTA and the reactivation reaction was started by the addition of the cytosolic phosphatase. The incubation was continued for a further $30 \mathrm{~min}$ and the phosphatase was inhibited by the addition of $50 \mathrm{~mm}-\mathrm{NaF}$. Treatment with the phosphatase reversed the effect of ATP on both $V_{\max }$ and apparent $K_{\mathrm{m}}$, and actually increased the $V_{\max }$ and $K_{\mathrm{m}}$ values of the enzyme above those of the control preparation (Table 1). Treatment of the non-inactivated microsomal preparation with cytosolic phosphatase for $30 \mathrm{~min}$ at $37^{\circ} \mathrm{C}$ resulted in a $30 \%$ increase in both $V_{\max }$. and $K_{\mathrm{m}}$ over the preparation preincubated in the absence of phosphatase (control). Both $V_{\max }$ and $K_{\mathrm{m}}$ values for the activated preparation were above the corresponding values for the reactivated preparation.

A comparison of the effects of activation, inactivation and reactivation on the isothermic kinetic constants of hydroxymethylglutaryl-CoA reductase in the microsomal preparation from rats fed the standard, cholesterol-supplemented and cholestyramine-supplemented diets

Microsomal fraction was obtained from the livers of rats fed the standard diet or a diet supplemented

Table 1. Effects of $\mathrm{ATP}+\mathrm{Mg}^{2+}$ and phosphatase on the isothermic kinetic constants of hydroxymethylglutaryl-CoA reductase in microsomal preparation from rats given the standard diet

Portions of the microsomal fraction $\left(15 \mathrm{mg}\right.$ of microsomal protein) were incubated at $37^{\circ} \mathrm{C}$ for $20 \mathrm{~min}$ in a total volume of $2 \mathrm{ml}$ containing $50 \mathrm{mM}$-imidazole $/ \mathrm{HCl} / 250 \mathrm{mM}-\mathrm{NaCl} / 5 \mathrm{~mm}$-dithiothreitol $(\mathrm{pH} 7.4)$ buffer plus $2 \mathrm{mM}$ ATP and $4 \mathrm{mM}-\mathrm{MgCl}_{2}$ for the inactivating preincubation, or no ATP $+\mathrm{Mg}^{2+}$ for the control preincubation. At the end of this incubation $2 \mathrm{ml}$ of $50 \mathrm{~mm}$-EDTA and $2 \mathrm{ml}$ of $150 \mathrm{~mm}-\mathrm{NaF}$ containing $25 \%$ glycerol were added to each flask and $0.2 \mathrm{ml}$ portions were removed to assay the activity of the enzyme. For the reactivation reaction $2 \mathrm{ml}$ of $50 \mathrm{~mm}$-EDT A and $1 \mathrm{ml}$ of phosphatase $(18.4 \mathrm{mg}$ of protein) were added at the end of the inactivating preincubation, and the incubation was continued for $30 \mathrm{~min}$ at $37^{\circ} \mathrm{C}$. NaF $(300 \mathrm{~mm}, 1 \mathrm{ml})$ was added and $0.2 \mathrm{ml}$ portions were removed to assay the activity of the enzyme. For the activation reaction a portion of the microsomal preparation $\left(15 \mathrm{mg}\right.$ of protein) was incubated at $37^{\circ} \mathrm{C}$ for $30 \mathrm{~min}$ in a total volume of $5 \mathrm{ml}$ containing $50 \mathrm{~mm}$-imidazole/HCl/ $250 \mathrm{~mm}-\mathrm{NaCl} / 5 \mathrm{~mm}$-dithiothreitol ( $\mathrm{pH} 7.4)$ buffer plus $25 \mathrm{~mm}$-EDTA and phosphatase (18.4 mg of protein). At the end of this incubation, $1 \mathrm{ml}$ of $300 \mathrm{mM}-\mathrm{NaF}$ was added and $0.2 \mathrm{ml}$ portions were removed to assay the activity of the enzyme. The activity of hydroxymethylglutaryl-CoA reductase was assayed in all cases in a total volume of $0.5 \mathrm{ml}$ and in the presence of various concentrations of DL-hydroxymethyl[ $\left[3-{ }^{14} \mathrm{C}\right]$ glutaryl-CoA $(10-180 \mu \mathrm{M}$; sp. radioactivity $6 \mathrm{Ci} / \mathrm{mol})$. The $K_{\mathrm{m}}$ and $V_{\max }$. values were calculated from Lineweaver-Burk plots, excluding values at substrate concentrations that inhibited enzyme activity. $K_{\mathrm{m}}$ values were calculated by using the concentration of DL-hydroxymethylglutaryl-CoA.

$\begin{array}{lcccc}\text { Reaction } & \text { No. of concentrations } & \text { Correlation coefficient } & V_{\max .}(\mathrm{nmol} / \mathrm{mg} \text { per } \min ) & K_{\mathrm{m}}(\mu \mathrm{M}) \\ \text { Control } & 7 & 0.994 & 0.314 & 19.5 \\ \text { Inactivation } & 7 & 0.999 & 0.109 & 8.1 \\ \text { Reactivation } & 7 & 0.997 & 0.380 & 27.2 \\ \text { Activation } & 8 & 0.994 & 0.409 & 31.4\end{array}$


Table 2. Isothermic kinetic constants of hydroxymethylglutaryl-CoA reductase in microsomal preparations from rats given the standard, cholesterol-supplemented and cholestyramine-supplemented diets

Three rats in each group involving animals given the standard diet, cholestyramine-supplemented or cholesterolsupplemented diet were killed at the same time and the livers from the rats in each group were pooled to prepare the microsomal fraction. The microsomal preparations were preincubated, activated, inactivated and reactivated as described in Table 1. At the end of the treatment portions of each preparation were incubated in the presence of various concentrations of $\mathrm{DL}$-hydroxymethyl[ $\left.3-{ }^{14} \mathrm{C}\right]$ glutaryl-CoA $(10-180 \mu \mathrm{M}$; sp. radioactivity $6 \mathrm{Ci} / \mathrm{mol})$ to assay the activity of the reductase. The $K_{\mathrm{m}}$ and $V_{\max }$. values were calculated from Lineweaver-Burk plots, excluding values at substrate concentrations that inhibited enzyme activity. Each plot included values obtained from five to nine different concentrations and in all cases the correlation coefficient was better than $0.990 . K_{\mathrm{m}}$ values were calculated using the concentration of DL-hydroxymethylglutaryl-CoA.

\begin{tabular}{|c|c|c|c|c|c|c|}
\hline \multirow[b]{2}{*}{ Reaction } & \multicolumn{2}{|c|}{ Standard diet } & \multicolumn{2}{|c|}{ Cholesterol diet } & \multicolumn{2}{|c|}{ Cholestyramine diet } \\
\hline & $\begin{array}{c}V_{\max } \\
(\mathrm{nmol} / \mathrm{mg} \text { per } \min )\end{array}$ & $\begin{array}{c}K_{\mathrm{m}} \\
(\mu \mathrm{M})\end{array}$ & $\begin{array}{c}V_{\max .} \\
(\mathrm{nmol} / \mathrm{mg} \text { per min) }\end{array}$ & $\begin{array}{c}K_{\mathrm{m}} \\
(\mu \mathrm{M})\end{array}$ & $\begin{array}{c}V_{\max .} \\
(\mathrm{nmol} / \mathrm{mg} \text { per } \min )\end{array}$ & $\begin{array}{c}K_{\mathrm{m}} \\
(\mu \mathrm{M})\end{array}$ \\
\hline Control & 0.645 & 32.4 & 0.195 & 8.0 & 5.730 & 230.9 \\
\hline Inactivation & 0.123 & 6.1 & 0.035 & 2.6 & 1.022 & 37.3 \\
\hline Reactivation & 0.631 & 32.1 & 0.168 & 6.0 & 4.589 & 177.9 \\
\hline Activation & 0.650 & 30.5 & 0.205 & 9.3 & 5.266 & 202.2 \\
\hline
\end{tabular}

with $5 \%$ cholestyramine or $2 \%$ cholesterol as described in the Materials and Methods section. The microsomal preparations were preincubated either in the absence (control), or in the presence, of $2 \mathrm{~mm}$ $\mathrm{ATP}+4 \mathrm{mM}-\mathrm{MgCl}_{2}$ (inactivated). Inactivated microsomal preparations were reactivated by a further 30 min incubation in the presence of phosphatase. As expected, the $V_{\text {max }}$ of the enzyme in control microsomes was very low in the preparation from rats given the cholesterol-supplemented diet, very high in rats given the cholestyramine-supplemented diet and intermediate in the preparation from rats given the standard diet (Table 2). The apparent $K_{\mathrm{m}}$ value for hydroxymethylglutaryl-CoA was high in the preparation from rats given the cholestyraminesupplemented diet, intermediate from rats given the standard diet and low in the preparation from rats fed the cholesterol-supplemented diet. However, there was no difference between the preparations in the degree of inactivation produced by ATP and $\mathrm{Mg}^{2+}$. In all three, the inactivation reaction reduced the $V_{\max }$ to about $20 \%$ of the value of the corresponding control preparation (Table 2). Inactivation also resulted in a considerable decrease in the apparent $K_{\mathrm{m}}$ for hydroxymethylglutaryl-CoA. The value for the inactivated preparation was $20 \%$ of that of the control preparation in rats given the standard diet, $32 \%$ of control values in rats given the cholesterol diet and $16 \%$ of control values in rats given the cholestyramine diet. Reactivation of all preparations resulted in a large increase in both $V_{\max .}$ and apparent $K_{\mathrm{m}}$ to values slightly below those for the corresponding control preparations (Table 2). Preincubation of non-inactivated microsomal preparations for $30 \mathrm{~min}$ at $37^{\circ} \mathrm{C}$ with phosphatase gave, in all cases, values of $V_{\max }$. and apparent $K_{\mathrm{m}}$ that were similar to, or greater than, those observed with the reactivated microsomal preparations (Table 2). Another experiment of the same design gave results similar to those in Table 2.

\section{Discussion}

The original observation (Beg et al., 1973) that hydroxymethylglutaryl-CoA reductase in the microsomes is inactivated during incubation in the presence of ATP $+\mathrm{Mg}^{2+}$, and that the inactivated enzyme can be reactivated by incubation in the presence of cytosol, has been confirmed in a number of laboratories. Furthermore, Nordstrom et al. (1977) partially purified, from liver cytosol, an $\left(\mathrm{ATP}+\mathrm{Mg}^{2+}\right)$-dependent inactivating system and a reactivating system that reversibly affected hydroxymethylglutaryl-CoA reductase activity, both in the microsomal fraction and when the enzyme was solubilized. Ingebritsen and his colleagues (Ingebritsen $e t$ al., 1978) have shown that the reductase-reactivating system may be replaced by a purified preparation of rat liver phosphorylase phosphatase. The present results are in complete agreement with these observations. Both the inactivation and the reactivation reactions were time-dependent and reactivation was dependent on the concentration of phosphorylase phosphatase. ADP could replace ATP in the inactivating system. Several other workers have also found that ADP could mimic the inactivation by ATP, although work on the specificity of various nucleotides in this process has been inconsistent (Goodwin \& Margolis, 1978).

The activation of hydroxymethylglutaryl-CoA reductase that occurs during preincubation of the 
untreated microsomal fraction was not inhibited by $\mathrm{NaF}$. Thus this effect, which has been attributed to a reversible cold inactivation of the enzyme (Heller \& Gould, 1975; Mitropoulos \& Venkatesan, 1977), is unlikely to be the same phenomenon as the reactivation or activation observed during incubation in the presence of phosphorylase phosphatase. Moreover, the reactivation or activation mediated by phosphorylase phosphatase results in an increase in both $V_{\max }$ and apparent $K_{\mathrm{m}}$ for hydroxymethylglutaryl-CoA, whereas activation on preincubation in the absence of phosphatase results in an increase in $V_{\text {max. }}$ with no change in apparent $K_{\mathrm{m}}$ (Mitropoulos \& Venkatesan, 1977).

We have shown previously (Mitropoulos \& Venkatesan, 1977) that feeding rats a diet supplemented with cholesterol results in a decrease in both $V_{\text {max. }}$ and apparent $K_{\mathrm{m}}$ for hydroxymethylglutaryl$\mathrm{CoA}$ of hydroxymethylglutaryl-CoA reductase assayed in microsomes subsequently prepared from liver. In contrast, feeding with cholestyramine leads to an increase in both the $V_{\max }$. and apparent $K_{\mathrm{m}}$. The results reported in the present paper show that treatment of microsomal preparations in vitro with ATP $+\mathrm{Mg}^{2+}$ results in a decrease in both $V_{\text {max. }}$ and apparent $K_{\mathrm{m}}$. Furthermore, reactivation of inactivated microsomes is associated with an increase in apparent $K_{\mathrm{m}}$ for hydroxymethylglutaryl-CoA reductase. Thus, qualitatively, cholesterol feeding produces a similar effect to inactivation in vitro and cholestyramine feeding produces a similar effect to reactivation or activation in vitro. However, the results also argue strongly against any possibility that the differences observed in untreated microsomal fraction from rats on the three diets can be explained by differences in the degree of phosphorylation of the reductase. Treatment with phosphatase did not significantly increase the $V_{\max }$. or apparent $K_{\mathrm{m}}$ in microsomes from animals given standard or high-cholesterol diets. Moreover, microsomes from each physiological condition were inactivated to the same extent by incubation with ATP $+\mathrm{Mg}^{2+}$, and were similarly reactivated by phosphorylase phosphatase. Nordstrom et al. (1977) have suggested that various phosphatases might act on hydroxymethylglutaryl-CoA reductase during homogenization of the tissue and isolation of the microsomes. This is a real possibility and, indeed, our data suggest that the enzyme in the microsomal preparations from rats on all three diets was fully dephosphorylated. Thus, there is little doubt that the modulation of hydroxymethylglutaryl-CoA reductase activity that follows cholesterol or cholestyramine feeding is not mediated through a mechanism involving phosphorylation or dephosphorylation of the enzyme. We do not exclude the possibility that the phosphorylation cycle could produce an effect in vivo, in addition to that produced by the concentra- tion of cholesterol in the micro-environment of the enzyme.

We have previously provided evidence suggesting that the changes in activity and kinetic properties of hydroxymethylglutaryl-CoA reductase in the microsomal fraction after the administration of dietary cholesterol and of cholestyramine are due to changes in the fluidity of endoplasmic-reticular membrane brought about mainly by changes in the concentration of cholesterol in the environment of the enzyme. The observation that the enzyme solubilized from the microsomal fraction from rats given cholesterol or cholestyramine had identical apparent $K_{\mathrm{m}}$ values for hydroxymethylglutaryl-CoA reductase (Mitropoulos \& Venkatesan, 1977) supports the proposal that the enzyme interacts with its lipid environment. In the present paper we demonstrate that modulation in vitro results in changes in the isothermic kinetic constants that are in the same direction as those produced by modulation in vivo by cholesterol. The extent to which the modulation in vivo and in vitro of hydroxymethylglutaryl-CoA reductase share a common mechanism requires further investigation.

\section{References}

Balasubramaniam, S., Venkatesan, S., Mitropoulos, K. A. \& Peters, T. J. (1978) Biochem. J. 174, 863-872

Beg, Z. H., Allman, D. W. \& Gibson, D. M. (1973) Biochem. Biophys. Res. Commun. 54, 1362-1369

Beg, Z. H., Stonik, J. A. \& Brewer, H. B., Jr. (1978) Proc. Natl. Acad. Sci. U.S.A. 75, 3678-3682

Berndt, J., Hegardt, I. G., Bove, J., Gaumert, R., Still, J. \& Cardo, M.-T. (1976) Hoppe-Seyler's Z. Physiol. Chem. 357, 1277-1282

Brandt, H., Capulong, Z. L. \& Lee, E. Y. C. (1975) J. Biol. Chem. 250, 8038-8044

Brown, M. S. \& Goldstein, J. L. (1974) J. Biol. Chem. 249, 7306-7314

Brown, M. S., Brunschede, G. Y. \& Goldstein, J. L. (1975) J. Biol. Chem. 250, 2502-2509

Chow, J. C., Higgins, M. J. P. \& Rudney, H. (1975) Biochem. Biophys. Res. Commun. 63, 1077-1084

Dietschy, J. M. \& Brown, M. S. (1974) J. Lipid Res. 15, 508-516

George, R., Menon, A. S. \& Ramasarma, T. (1978) Biochem. Biophys. Res. Commun. 84, 544-549

Goodwin, C. D. \& Margolis, S. (1978) J. Lipid Res. 19, 747-756

Heller, R. A. \& Gould, R. G. (1975) Biochim. Biophys. Acta 388, 254-259

Higgins, M. \& Rudney, H. (1973) Nature (London) New Biol. 246, 60-61

Ingebritsen, T. S., Lee, H.-S., Parker, R. A. \& Gibson, D. M. (1978) Biochem. Biophys. Res. Commun. 81, $1268-1277$

Mitropoulos, K. A. \& Venkatesan, S. (1977) Biochim. Biophys. Acta 489, 126-142 
Mitropoulos, K. A., Balasubramaniam, S. \& Myant, N. B. (1973) Biochim. Biophys. Acta 326, 428-438

Mitropoulos, K. A., Venkatesan, S. \& Balasubramaniam, S. (1978a) Biochem. Soc. Trans. 6, 878-883

Mitropoulos, K. A., Balasubramaniam, S., Venkatesan, S. \& Reeves, B. E. A. (1978b) Biochim. Biophys. Acta 530, 99-111

Mitropoulos, K. A., Venkatesan, S. \& Balasubramaniam,
S. (1979) in Biological Effects of Bile Acids (Paumgartner, G., Stiehl, A. \& Gerok, W., eds.), vol. 5, pp. 137-144, MTP Press, Lancaster

Nordstrom, J. L., Rodwell, V. W. \& Mitschelen, J. J. (1977) J. Biol. Chem. 252, 8924-8934

Rodwell, V. W., McNamara, D. J. \& Shapiro, D. J. (1973) Adv. Enzymol. Relat. Areas Mol. Biol. 38, 373412 